\title{
Mariopteris, Dicksonites and Fortopteris from the Dobrudzha Coalfield, Bulgaria
}

\author{
Yanaki Georgiev Tenchov \\ Geological Institute, Bulgarian Academy of Sciences, Acad. G. Bonchev St., Bl. 24, 1113 Sofia, Bulgaria; \\ e-mail: ytenchov@abv.bg
}

(Accepted in revised form: November 2012)

\begin{abstract}
In the Dobrudzha Coalfield, mariopterids are found frequently. They are creeping plants associated with flood plain sediments. The changes in architecture and species composition are clearly connected with variations in rain falls and the onset of periods of long, dry conditions. One specimen with seeds attached on the lower surface of a pinna proves that Mariopteris belongs to the pteridosperms. Dicksonites and Fortopteris are rare.
\end{abstract}

Tenchov, Y. G. 2012. Mariopteris, Dicksonites and Fortopteris from the Dobrudzha Coalfield, Bulgaria. Geologica Balcanica 41(1-3), 39-51.

Key words: Mariopteris, attached seed, habitat, creeping, climate, Dobrudzha Coalfield.

\section{INTRODUCTION}

This study presents details of the species diversity of the genus Mariopteris in the Dobrudzha Coalfield, its habitat and vertical distribution, and the interpretation of climatic changes that may have influenced the species composition. The paper will also document a specimen with a seed attached.

Specimens of Mariopteris are abundant among the collected samples from the Dobrudzha Coalfield, with about 580 among the 11800 collected slabs (4.9\%) having example of that genus. They belong to eight species (about $3 \%$ of the total of about 300 plant species that have been identified in the Dobrudzha Coalfield). The most abundant species is M. muricata, with 346 examples having been found. In addition, there are $M$. acuta (105 examples), M. nervosa (76 examples), M. carnosa (24 examples), M. beneckeii (12 examples), M. sarana (10 examples), M. soubeirianii ( 2 examples) and M. robusta (1 example). There are also 3 examples of Fortopteris latifolia and 14 examples of Dicksonites plueckenetii. They are unevenly distributed in the sequence (Fig. 1), occurring mainly in the Mogilishte Formation (Yeadonian to Duckmantian), less commonly in the Makedonka Formation (late Duckmantian and Bolsovian), rare in the Krupen Formation (Late Bolsovian to Early Asturian) and quite rare in the Gurkovo Formation (late Asturian to early Cantabrian).
In the rest of the paper, the following abbreviations will be used: DC for Dobrudzha Coalfield; F. for Formation; SL for level above coal seam 11 at the base of the Mogilishte Formation or (with a negative value) for a level in the Rakovski Formation below coal seam 11.

\section{HABITAT AND REPRODUCTION}

The habitat of the mariopterids has not been widely discussed. The opinion of Gothan (1913, p. 88) that Mariopteris was a part of the subforest vegetation as creeping and climbing plants, is widely quoted but there is little evidence to support the idea. Kerp and Barthel (1993, Plate 5, Figs 1-4) suggested that epidermal hooks on Karinopteris pinnae is evidence that they were fronds of climbing plants, but these are most probably Eusphenopteris less probably Sphenopteris. So, the climbing is not supported by facts.

In the Dobrudzha Coalfield, Mariopteris specimens were collected from all coal-bearing lithostratigraphic units. They were rare in the Rakovski Formation (Namurian A), frequent in the Mogilishte, Makedonka and Krupen formations (Namurian C - Asturian), and rare upwards into the Stephanian (Gurkovo Formation). They are rare in fluvial deposits and in the coals, where only rare allochthonous fragments are found. As autochthonous remains, they are most frequent in the rocks im- 


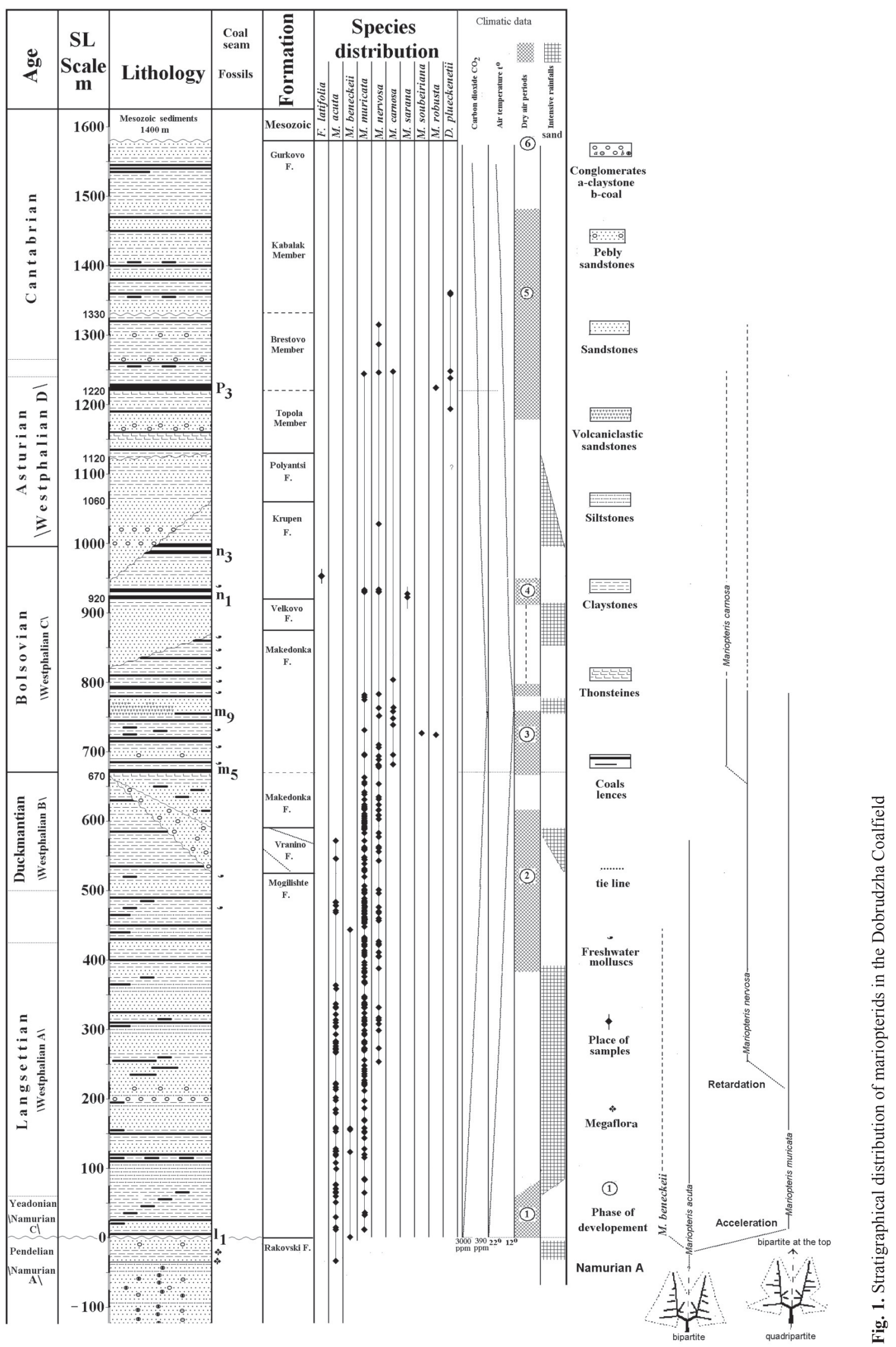


mediately overlying coal seams, especially in the upper part of the Mogilishte Formation.

In floodplain conditions, the mariopterid plants intertwined to form a thick carpet cover. Here and there were also included some bush-like plants of Sphenophyllum and some seed ferns such as Neuralethopteris, Alethopteris and Eusphenopteris. Associated paripterid remains are allochthonous. The remains of seeds are autochthonous, however, as they could not germinate in the full shadow and cold conditions below the Mariopteris carpet.

During flooding, the creeping plants were covered by muddy water and some amount of mud would have covered everything. That is why Mariopteris has no stomata on the upper surface, as they would have been plugged up by the mud. The stalk is massive to support the large leaves and the mud covering them after the flood. After withdrawal of the water the mud cover may have been washed off by rainfall but, if the mud cover dried on the plant, it should kill it. In those cases when the floods covered the flood plain with deep water, the amount of the mud cover would have been so thick and heavy that it would have smashed the Mariopteris plants. That is the reason the leaf fossils tend to be preserved mainly showing their upper surface.

Their preferred habitat was the flood plain (Tenchov, 2012) and levee (the first flood terrace) where they are found concentrated in practically each bed. In intervals built by flood plain deposits that are thicker than one meter, they are collected up to 8 slabs each meter, each slab being about $1 \mathrm{~cm}$ thick. Two such drill intervals are sampled in the Krupen F., two in the Makedonka F., and 20 in the Mogilishte F. From drill R218 at 1406 m, in a onemeter thick interval seven samples were collected with Mariopteris and another two with Eusphenopteris. The non-exposed parts of the slabs could also be seen to contain plant remains. The plant remains were smashed by the settling down of the turbid flood waters, or died after the reproductive phase. In both cases, they are found with their upper surface facing upwards. Leaves preserved showing their lower surface, reversed by some reason, are rarely found and illustrated. This suggests that mariopterids favoured places with low water dynamics.

It is widely assumed that the mariopterids were pteridosperms but there is little evidence to confirm this (Gothan, 1935, p. 8-14). Gothan suggested the possibility of vegetative reproduction by means of buds. The possibility that Mariopteris was a seed-plant is at least partly based on an analogy with Dicksonites plukenetii, which is known to have had small seeds situated on the lower surface of its pinnae. As Mariopteris in the main tends to be preserved showing the upper surface stimulated me to inspect slabs with Mariopteris in the Dobrudzha Coalfield collection. This study revealed a seed-bearing Mariopteris beneckeii (samples №№ 16343 and 16344, part and counterpart) shown in Fig. 2: 5, 7. This originated from drill R218 at $1406 \mathrm{~m}$ depth, which corresponds to about $218 \mathrm{~m}$ above the base of the Mogilishte F., in the middle part of the Langsettian Substage. It is from a young leaf, part of which is reversed and shows the lower surface with at least two small seeds.

The position of the seed-bearing part in the quadripartite mariopterid fronds is a problem - was it on the bipartite part or on the quadripartite part? Most probably it was on the bipartite frontal part of the plant, inherited from the bipartite origin of the quadripartite fronds. In such a case, the chance of finding a seed-bearing part of a quadripartite Mariopteris is rather low. Boersma (1972) only documented three bipartite examples, none of which showed the lower surface of the pinna. Of the figured quadripartite parts, nearly all are showing the upper surface and therefore cannot demonstrate seeds. The same is so in the DC.

This rare discovery leads to the hypotheses that Mariopteris, as with many other ancient plants (e.g. some lepidodendrons) after a period of vegetative growth entered a reproductive phase, and then died. Two advantages in this are that (a) the seed is released far from rooting system of the mother plant (6 $\mathrm{m}$ or more), maybe away from the Mariopteris carpet, and thereby enlarging its habitat; and (b) the mother plant opens up a new place in the habitat for the new generation. The existing information does not permit us to appreciate how much the reproductive pinnae represent of the top of the plant. It can, however, be supposed that one or two quadristychs are reproductive, that is they may represent 5 or $10 \%$ of the length of one adult plant.

This reproduction strategy may be connected with the floods. The central part of the flood plain that became covered by deep water would lose all of its Mariopteris carpet, but that carpet would be rapidly restored. For fern plants this would have been easy to realize. For Mariopteris there are various possibilities that are at present hypothetic such as a rapid spread from an area outside of main part of the flood or the recovery of individuals from their top parts.

\section{TAXONOMIC PROBLEMS}

The taxonomic history of Mariopteris starts with the introduction of the name by Zeiller (1878) and the publication of a diagnosis by the same author (Zeiller, 1879). The numerous attempts to organize some better internal grouping of the increasing number of new species and revisions are critically analysed by Boersma (1972). He excluded a part of the plants as being real fern and placed them in a new genus, Fortopteris Boersma, 1969. The bipartite leaf possesses exterior pinna that gradually diminishes in length. The quadripartite leaf possesses a long pinna at the base of the tertiary rachis, followed by a pinna of calceolate form. On the basis of the architecture of the stem and detail study of the form of leaves he recognized two groups - one with bipartite and the other with quadripartite foliage, and he assigned them to two genera: Mariopteris Zeiller emend. Boersma, and Karinopteris Boersma. Numerous taxa previously included in Mariopteris or related to the genus were excluded from both of these genera.

Danzé-Corsin (1953, p. 57-58, p. 256) indicated that several Mariopteris species had quadripartite leaves in the lower part of the plant but bipartite leaves in the subterminal part. The transition of bipartite to quadripartite leaves is documented by her (Danzé-Corsin, 1953, Pl. 40, Fig.1; Pl. 10, Fig. 1, respectively pl. 11, Fig. 2). She (idem, p. 58, 
Plate 56) supposed that simple pinnae were situated at the terminal part of the stem but this is not evident from the plate. Boersma (1972) made no mention of simple pinna, but did mention that species with quadripartite leaves had a few bipartite leaves in the top part of the plant, which he referred to as aberrant "mini-fronds" or "aberrant forms" specimens of Mariopteris Zeiller emd. Boersma: $M$. nervosa (Kidston, 1925, Pl. 144, Figs 4, 4a); M. sauveurii (Boersma, 1972 Pl. 5, Fig.10); M. muricata (Boersma, 1972, P1. 21, Fig. 55). All of them are regarded as "minute fronds of Mariopteris". His opinion was (p. 68): "At present the few aberrant fronds...do not reject the practical morphological concept..." Although he did not comment on the opinion of Danzé-Corsin his observations are in indirect agreement with her. However, he did not discuss whether the generic name Karinopteris should be applied to the bipartite leaves at the top of the quadripartite plants.

The evidence presented by Boersma leads to a classification of mariopterids into (1) those species that consistently have bipartite leaves (Karinopteris Boersma), and (2) those species that mostly have quadripartite leaves but with some bipartite leaves in the upper part of the plant (Mariopteris Zelller emend. Boersma). Since these clearly only represent subgroups of a natural grouping of frond-types they ought only to be regarded as subgenera. Consequently, in the present study these taxa have not been used.

The drill core from which the specimens were collected in the Dobrudzha Coalfield was at most $106 \mathrm{~mm}$ in diameter, frequently $78 \mathrm{~mm}$, and in some drills and intervals only $52 \mathrm{~mm}$. The large size of Mariopteris leaves (up to $760 \mathrm{~mm}$ ) compared with the size of the studied samples means that many examples can be determined only to generic level. Nevertheless, I think that it is better to record them all.

\section{SYSTEMATIC PART}

\section{Mariopteris acuta (Brongniart) Zeiller \\ Fig. 2: 1-4}

1886. Mariopteris acuta; Zeiller, p. 164, Fig. 2; Pl. 2, Fig. 16. 1953. Mariopteris acuta; Danzé-Corsin, p. 76, Fig. 13; Pts I-VII. 1972. Karinopteris acuta; Boersma, p. 135, Fig. 15; pts 32-35.

Description. Bipartite fronds characterised by dentate pinnules, broadly inserted at the base, permitting easy identification. There are also some pinnules with a "sphenopterid" attachment (Danzé-Corsin, 1953, P1. 2, Fig. 2). Gothan (1935) distinguished several forms - such as forma obtusa (Fig. 2. 3).

Distribution. In Dobrudzha Coalfield this species was found in the Rakovski F. (Namurian) in drill R222, $1583 \mathrm{~m}$, which is about $301 \mathrm{~m}$ below the top of the Rakovski F. (specimen 16539; Fig. 2. 4). M. acuta is frequent in the Mogilishte F. at 61 levels in the Yeadonian Substage (SL $1,12,15,30,51,60,65,65,66,70,71,71,77,100,109$, $119,120,125,128,137,137)$, frequent in the Langsettian Substage (SL 153, 157, 159, 180, 185, 198, 198, 202, 214, 217, 221, 222, 222, 267, 267, 268, 270, 272, 277, 280, 282, 284, 293, 304, 305, 310, 314, 322, 331, 333, 337), and rare in the lower part of the Duckmantian Substage (SL 421, 426, 469, 471, 479, 483, 484, 547, 572). It seems that the last two levels are the highest known occurrences of this species in the Variscan foredeep.

\section{Mariopteris beneckeii Huth}

Fig. 2: 5-7

1912. Mariopteris Beneckei; Huth, p. 9; Figs 1-8;

1953. Mariopteris Beneckei; Danzé-Corsin, p. 100; Fig. 16; Pts 14, 15;

1972. Karinopteris beneckeii; Boersma, p. 76.

Desription. Bipartite fronds in which the veins are not well preserved, although they tend to be clearer on the lower surface of the pinnae. The sphenopterid form of pinnules and the widely spaced lobes closely resemble the specimens figured by Huth (1912). The species is rare, known mainly from the Silesian Basin and rarely in France. In DC most specimens were collected from the upper Langsettian to lower Duckmantian parts of the Mogilishte F. In addition, one specimen came from the upper Yeadonian (SL1), three from the lower Langsettian Substage (SL 124, 156, 158) and one possible example from the basal Bolsovian Substage (SL 444).

Distribution. Specimen 16344 has seeds attached to the lower surface of a pinnule (Fig. 2. 7, 7A). The specimen seems to be part of a frond from the upper part of the stem based on its small pinnules. This position of the seeds would have helped with their dispersal away from the mother plant. It is comparable with Dicksonites plukenetii, which also had small seeds on the lower surface of the pinnules.

\section{Mariopteris soubeirianii Zeiller \\ Fig. 3: 1}

1888. Mariopteris soubeiriani; Zeiller, p. 167; Pl. 19, Fig. 1 (copy in Boersma, 1972, Pl. 26, Fig. 60).

1972. Mariopteris soubeiriani; Danzé-Corsin, p. 209; Fig. 36; Pts 64-66.

1972. Karinopteris soubeirianii; Boersma, pp. 77, 139; Textfig. 16; P1. 26, Fig. 60; Pts 36, 37.

Description. This species is known to have had bipartite fronds.

Distribution. One specimen found in the DC compares well with the specimen figured by Danzé-Corsin (1972, P1. 64, Fig. 1). The DC specimen is from the middle Bolsovian part of the Makedonka F in drill R199 at 1919 m (SL 727).

\section{Mariopteris robusta Kidston ex Danzé-Corsin}

Fig. 3: 2

1972. Mariopteris robusta; Danzé-Corsin p. 177; Fig. 30; Pts 64-66.

1972. Karinopteris robusta; Boersma, p. 77; Pl. 26, Fig. 13; Pl. 27, Fig. 63.

The figured specimen is from the Bolsovian part of the Makedonka F. (SL 737), and has pinnules that correspond 

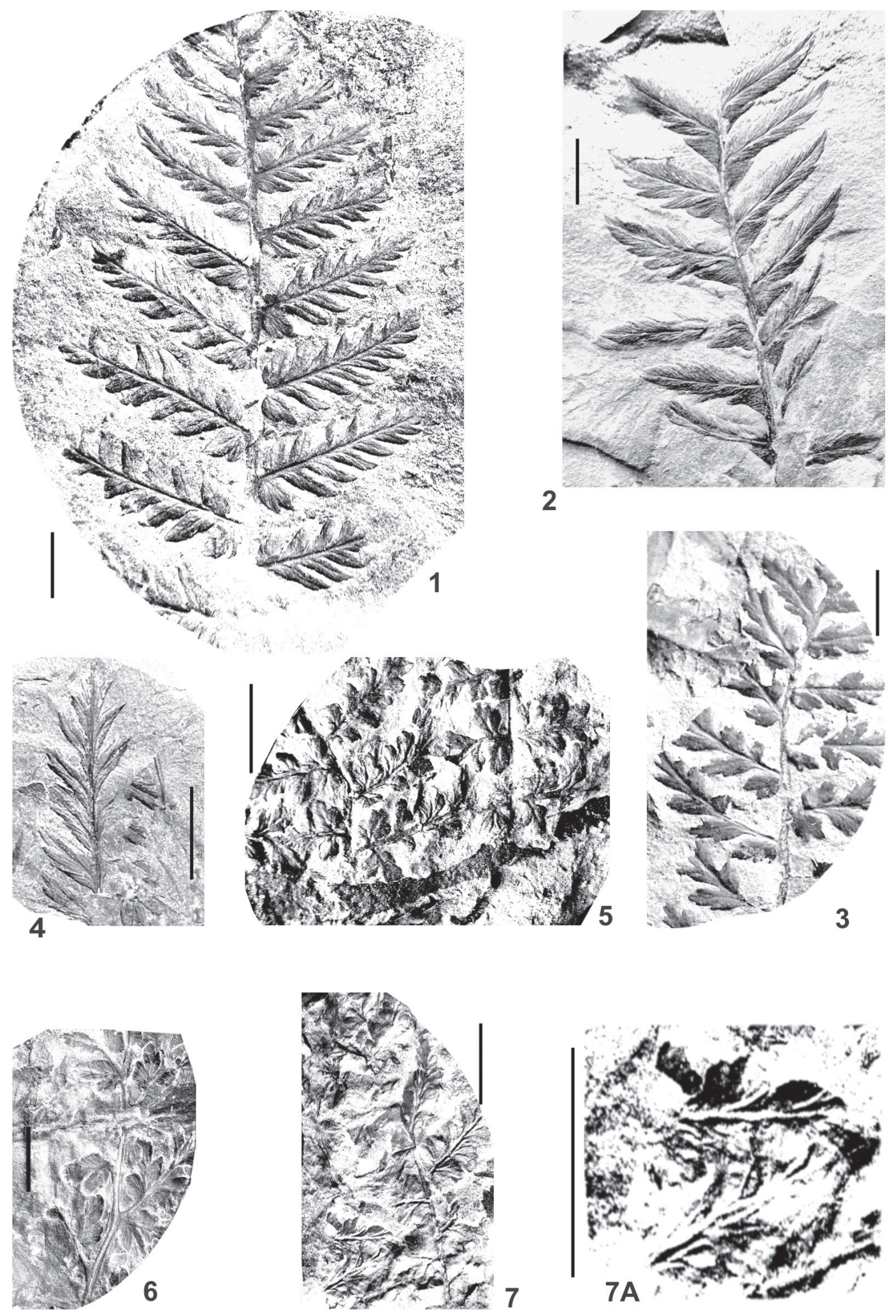

Fig. 2. All figures from Mogilishte Formation except stated otherwise. Bar $1 \mathrm{~cm}$.

1 - Mariopteris acuta, sample 14089, drill R148, 1957 m, Duckmantian, SL 572.

2 - Mariopteris acuta, sample 08570, drill R90, 1794 m, Langsettian, SL 314.

3 - Mariopteris acuta f. obtuse, sample 08747, drill R93, 1395 m, Langsettian, SL 295.

4 - Mariopteris acuta, sample 16539, drill R222, 1583 m, Rakovski Fm, Namurian A, SL -301.

5 - Mariopteris beneckeii, sample 16343, drill R218, 1406 m, Langsettian, SL 295.

6 - Mariopteris beneckeii, sample 16299, drill R217, 1439 m, Langsettian, SL 156.

7, 7A - Mariopteris beneckeii, sample 16344, drill R218, 1406 m, Langsettian, SL 295. Attached seed. 

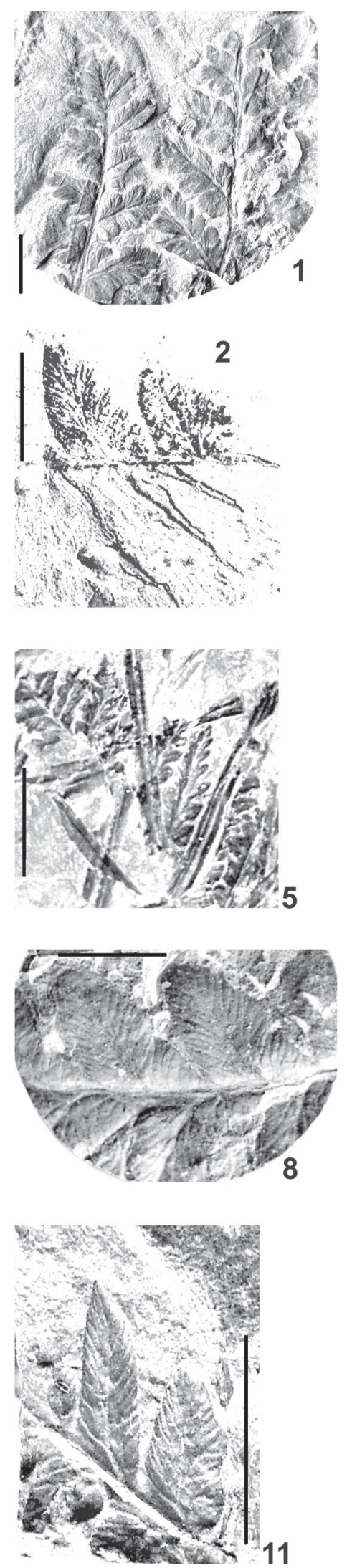

A 1 .
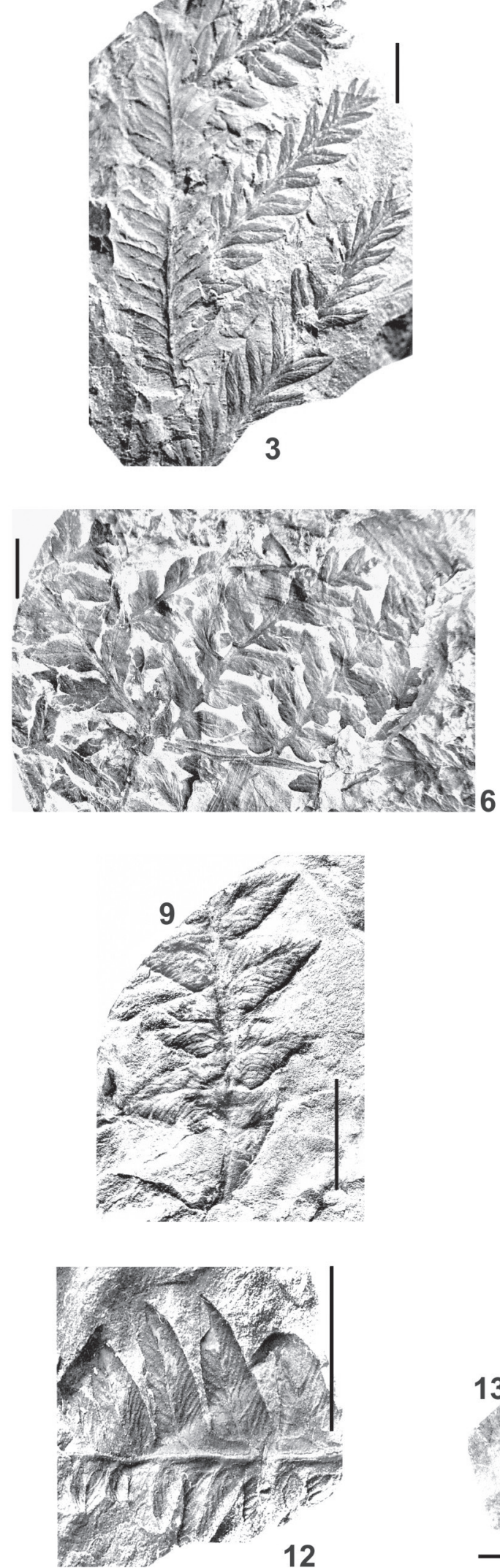
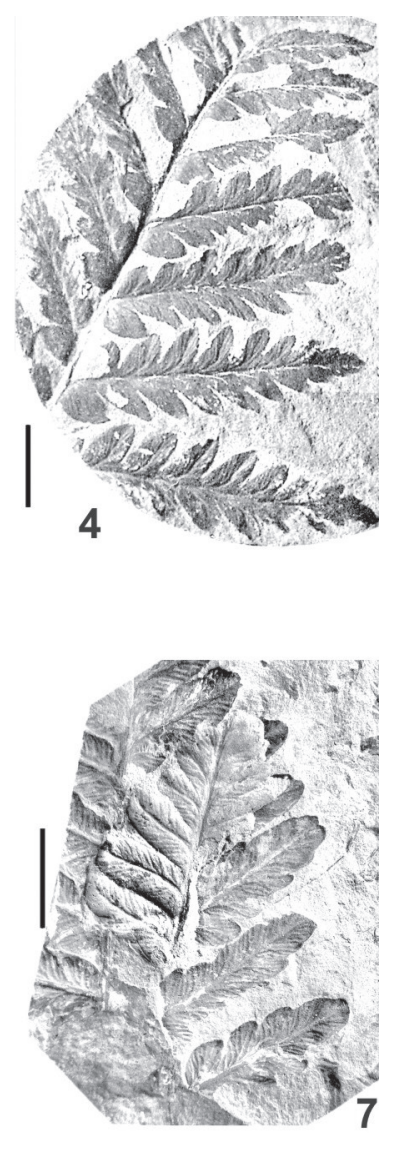
Fig. 3. All figures from Makedonka Formation except stated otherwise. Bar $1 \mathrm{~cm}$.

1 - Mariopteris soubeirianii, sample 15501, drill R199, 1919 m, Bolsovian, SL 727.

2 - Mariopteris robusta, sample 12564,_drill R137, 1540 m, Bolsovian, SL 737.

3 - Mariopteris muricata, sample 06182, drill R71, 1754 m, Mogilishte F. Duckmantian, SL 478.

4 - Mariopteris muricata, sample 06391, drill R84, 1859 m, Late Duckmantian, SL 661.

5 - Mariopteris muricata, small pinnules from top of the plant, sample 09445, drill R95, 1912 m, Bolsovian, SL 680.

6 - Mariopteris muricata, sample 05352, drill R 66, 1947 m, Mogilishte F., Langsettian, SL 429.

7 - Mariopteris nervosa, sample 14655, drill R159, 1403 m, Gurkovo Fm, Asturian, SL 1138.

8 - Mariopteris nervosa, sample 05629, drill R54, 1962 m, Bolsovian, SL 678.

9 - Mariopteris carnosa, sample 09326, drill R95, 1602 m, Bolsovian, SL 680.

10 - Mariopteris carnosa, sample 12591, drill R54, 1962 m, Bolsovian, SL 678.

11 - Mariopteris carnosa, sample 08263, drill R81, 1788 m, Bolsovian, SL 746.

12 - Mariopteris carnosa, sample 0826, drill R81, 1788 m, Bolsovian, SL 746.

13 - Mariopteis sarana, sample 06282, drill R84, 1572 m, Krupen F., Bolsovian, SL 932.

in size and veining with those shown by Danzé-Corsin (1972). The species is only known from small parts of its frond. Two other samples $(05811,05812)$ from a very similar stratigraphical level preserve similar but smaller leaves that more resemble $M$. sauveurii. However, as they are not so well preserved, that are catalogued as Mariopteris sp. (?sauveurii).

\section{Mariopteris muricata (Schlotheim) Zeiller}

Fig. 3: 3-6

1879. Mariopteris muricata; Zeiller, p.71; Pl. 47, Fig. 5. 1885. Diplotmema muricatum; Stur, p. 393; Pl. 21, Figs 1-6; P1. 22, Figs 1, 2; P1. 33, Figs 1, $2,4$.

1886-88. Mariopteris muricata; Zeiller, P1. 20, Figs 2, 3; P1. 21 Fig. 1.

1912. Mariopteris muricata; Huth, 12 pp.; Figs 1-5.

1953. Mariopteris muricata; Danzé-Corsin, p. 122; Pts 22-28. 1972. Mariopteris muricata; Boersma, p. 115; Pts 14-25.

Description. The quadripartite leaves have very variable pinnules, some with a wide base, others more constricted. For the former, the presence or absence of denticulation helps its delimitation from $M$. acuta. In some cases, the separation from $M$. nervosa can be problematic. One specimen (09445; Fig. 3. 5) is probably from the bipartite top of the plant (a "mini frond" of Boersma, 1972, P1. 21, Fig. 55). Sample 5172 is the top of a young specimen in its early phase of development, but is not well preserved.

Distribution. This species is the most widespread mariopterid in Dobrudzha Coalfield. 164 samples are related to this species. Of these, 132 are from the Mogilishte F.: 3 from the Yeadonian Substage (SL 12, 34, 37); 73 from the Langsettian Substage (SL 65, 66, cf. 84, 85, 116, cf120, 128, 144, 152, 153, 153, 158, 169, 170, 187, $198,212,212,220,221,222,224,227,233,236,240$, $243,248,256,270,270,272,273,280,282,283,293$, 293, 294, 298, 299, 307, 307, 308, 312, 314, 317, 324, $331,332,335,336,337,337,340,345,346,357,367$, $368,369,376,382,383,383,384,388,393,397,406$,
$409,411,414) ; 10$ from the Duckmantian Substage (SL 420, 422, 423, 427, 428, 430, 432, 432, 433, 449); and 46 from the Bolsovian Substage (SL 453, 454, 456, 457, 458, 459, 460, 461, 466, 467, 470, 472, 475, 477, 479, 482, 483, 484, 484, 486, 489, 496, 496, 497, 500, 502, $507,520,528,529,531,531,539,545,548,548,559$, $560,561,562,572,583,589,590,591,593)$. The species is still frequent in the Makedonka F.: 22 from the Duckmantian Substage (SL 596, 597, 598, 599, 600, 604, 606, 606, 608, 609, 610, 617, 618, 619, 621, 624, 631, $639,642,654,656,663)$ but only 6 from the Bolsovian Substage (SL 695, 696, 731, cf775, 779, 782). Just 3 specimens came from the Bolsovian Krupen F. (SL 930, 931, 933).

\section{Mariopteris nervosa (Brongniart) Zeiller Fig. 3: 7-8}

1932. Mariopteris nervosa; Corsin, p. 129; Pts 61-67.

1935. Mariopteris nervosa; Gothan, p. 27; Pl. 33, Figs 1, 2.

1953. Mariopteris nervosa; Danzé-Corsin p. 154; Pts 37-40.

1972. Mariopteris nervosa; Boersma, p. 84; P1. 10, Figs 20, 21.

Description. Semi-elliptic pinnules without denticulation or undulation permit easy recognition of this species. In DC it is not as frequent as in more western parts of Variscan foredeep.

Distribution. The samples were found in the middle part of the Dobrudzha sequence. From the Mogilishte F. 26 of them were found in middle Langsettian to lower early Duckmantian strata (SL 254, 273, 299, 308, 314, 317, 332, 388, 405, 411, 422, 424, 427, 457, 460, 469, 470, $476,496,501,543,556,561,563,578,583)$. They were rarely found in the Makedonka F. despite there being numerous drillings in that interval. Seven were found below the base of the Bolsovian Substage (SL 603, cf609, 616, 624, 632cf, 635, 654). Above the Bolsovian base, coals and lacustrine sediments prevail, and despite the numerous drills, only 11 specimens were found, characterised by more oblong pinnules (SL 678, 678, 680, 681, $688,694,706,710,752,763,783)$. In the Krupen F., 

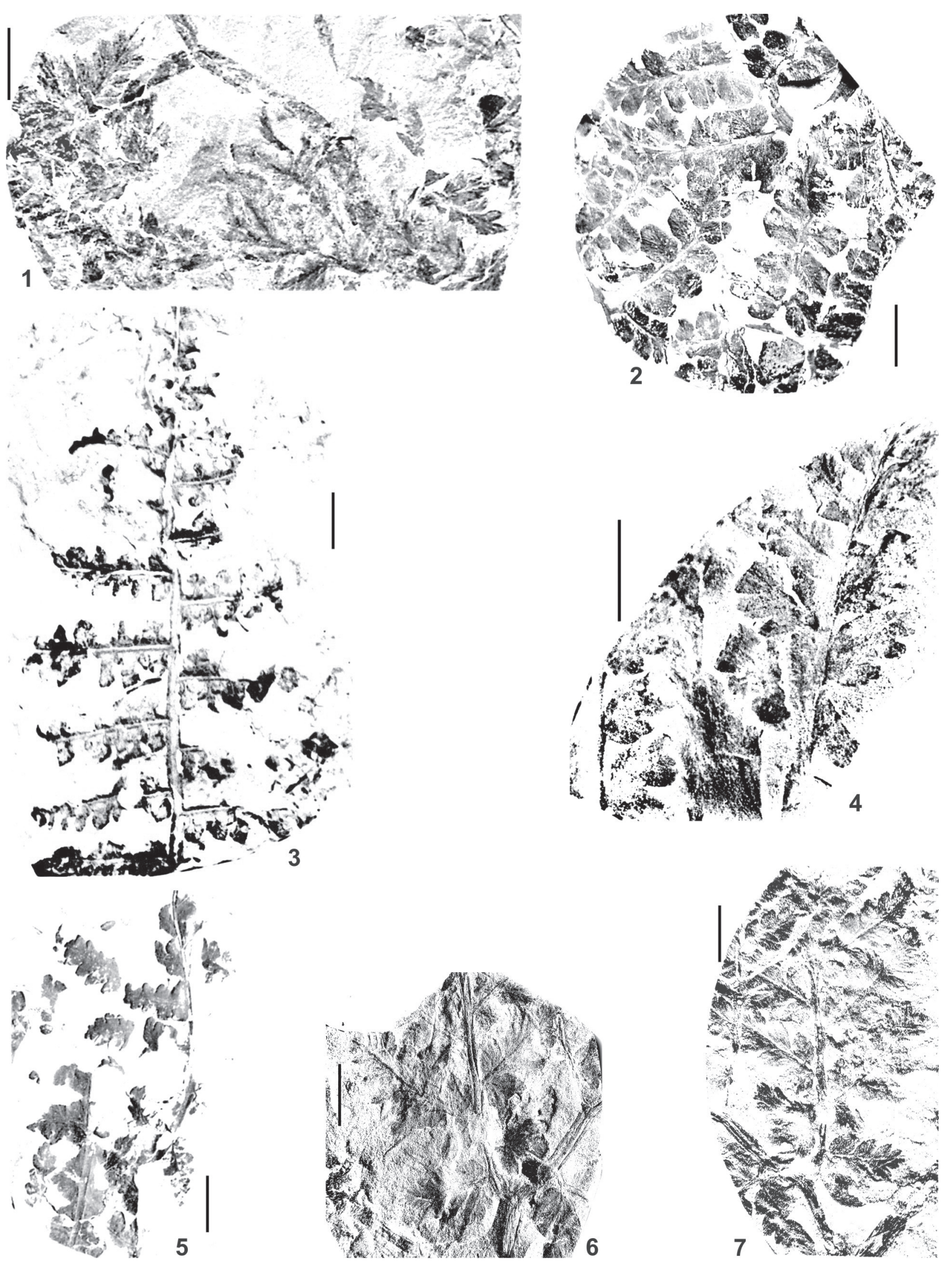
Fig. 4. Mariopterids from the Dobrudzha Coalfield. Bar $1 \mathrm{~cm}$

1 - Fortopteris latifolia, sample 16178, drill R213, 1411 m, Mogilishte Fm, Langsettian, SL 459.

2 - Dicksonites plukenetii, 11518, drill R108, 1643 m, Gurkovo Fm, Cantabrian, SL 1308.

3 -Dicksonites plukenetii, sample 05018, drill R67, 1452 m, Gurkovo Fm, Late Asturian, SL 1238.

4 - Mariopteris sarana, sample 06281, drill R84, 1572 m, Krupen Formation, Bolsovian, SL 932.

5 - Dicksonites plukenetii, sample 12736, drill R139, 1469 m, Gurkovo Fm, Cantabrian, SL 1359.

6 - Fortopteris latifolia, sample 05218, drill R66, 1478 m, Krupen Fm, Late Bolsovian, SL 932.

7 - Fortopteris latifolia, sample 05215, drill R66, 1478 m, Krupen Fm, Late Bolsovian, SL 932.

they were found immediately overlying coal seams $\mathrm{n} 1$ (S1 930, 931, 934) and n3 (SL 1028). One specimen only is from the Gurkovo F. (SL 1246) also from immediately above a coal seam.

\section{Mariopteris carnosa Corsin}

Fig. 3: 9-12

1932. Mariopteris carnosa; Corsin, p. 135; Pts 68-74.

1953. Mariopteris carnosa; Danzé-Corsin, p. 167; Pts 45-47.

1972. Mariopteris nervosa; Boersma (pars), pp. 98-100.

Description. Corsin did not indicate a holotype and so all the figured are syntypes. He distinguished it from $M$. nervosa by its more deltoid pinnules with an undulate border, and the less elevated nervation. Boersma (1972, p. 98) was of the opinion that $M$. carnosa is conspecific with $M$. nervosa, the more triangular aspect of the pinnules being due to enrolment of the margin. However, the Dobrudzha specimens do not have enrolled margins. Boersma regarded the other differences between the species as being within the range of variability of a single species, but he did not clarify that range. Both species are really similar in morphology, but with clear difference as indicate by Corsin. In Dobrudzha, the specific triangular pinnules appear in the Bolsovian (SL 680), whereas $M$ nervosa starts at SL 278 in the Langsettian Substage and is most frequent before SL 680, after which it is as frequent as M. carnosa. We have to accept that they are distinct species.

Distribution. Sample 08263 (Fig. 3. 11) shows that the first basiscopic lateral vein (b1) branches from the main vein. The species is known from 8 levels, 7 in the Bolsovian Makedonka F. (SL 680, 694, 694, 737, 746, 756, 762, 802) and one in the Asturian Gurkovo F. (SL 1246).

\section{Mariopteris sarana Huth}

Fig. 3: 13; Fig. 4: 4

1912. Mariopteis sarana; Huth, p. 150; Figs 1-4.

1932. Mariopteis sarana; Corsin, p. 170; P1. 55, Fig. 3; P1. 56, Figs 1-3.

1972. Mariopteis sarana; Boersma, p. 37.

A few specimens from Dobrudzha fit well with the illustrations given by Huth and Corsin. The veining is not well preserved and the attribution to the genus is disputable.
Boersma suggested that it is some form of Sphenopteris; Corsin indicated a similarity with Diplotmema schatzlarense but left it in Mariopteris. The Dobrudzha specimens do not contribute to the discussion. M. sarana in Dobrudzha is restricted to the upper Bolsovian part of the Krupen F. (SL 932, 936, 936).

\section{Dicksonites plukenetii (Schlotheim) Sterzel} Fig. 4: 2, 3, 5

1953. Dicksonites pluckeneti; Danzé-Corsin, p. 15; Figs 1-3; 1972. Dicksonites pluckeneti; Boersma, p. 31; Pl. 3, Figs 5, 6.

Nearly all the collected samples most probably had been dried before fossilization. They are with a diminished size of pinnules and veining is not observable. The exception is the specimen shown in Fig. 4. 5 that is well preserved. The drying was so intensive that in the strata immediately overlying coal seam $\mathrm{p} 3$ there are observed drying cracks. The species is found in the Gurkovo F., only in the top part of the Asturian Substage (SL 1194) and the lower part of the Cantabrian Substage (SL 1238, $1248,1359,1360)$.

\section{Fortopteris latifolia (Brongniart) Boersma}

Fig. 4: 1, 6, 7

1879. Mariopteris latifolia; Zeiller, p. 98; Pl. 6;

1953. Mariopteris latifolia; Danzé-Corsin, p. 230; Fig. 89; Pts 73-76;

1969. Fortopteris latifolia; Boersma, p. 25; P1. 2, Figs 3, 4.

The pinnules are ovate and the stem has clearly marked longitudinal ribs rather than transverse bars (as in Mariopteris). The veining is not clearly visible, but is in agreement with that of $F$. latifolia. Only a few specimens can be compared with this species, from the basal Duckmantian Mogilishte F. (SL 454) and the upper Bolsovian Krupen F. (SL 953).

\section{DISCUSSION}

Mariopterids are well represented in all Upper Carboniferous deposits of the Dobrudzha Coalfield. The species diversity is similar to that in the other basins of the Variscan foredeep in Europe for the time span Namurian 


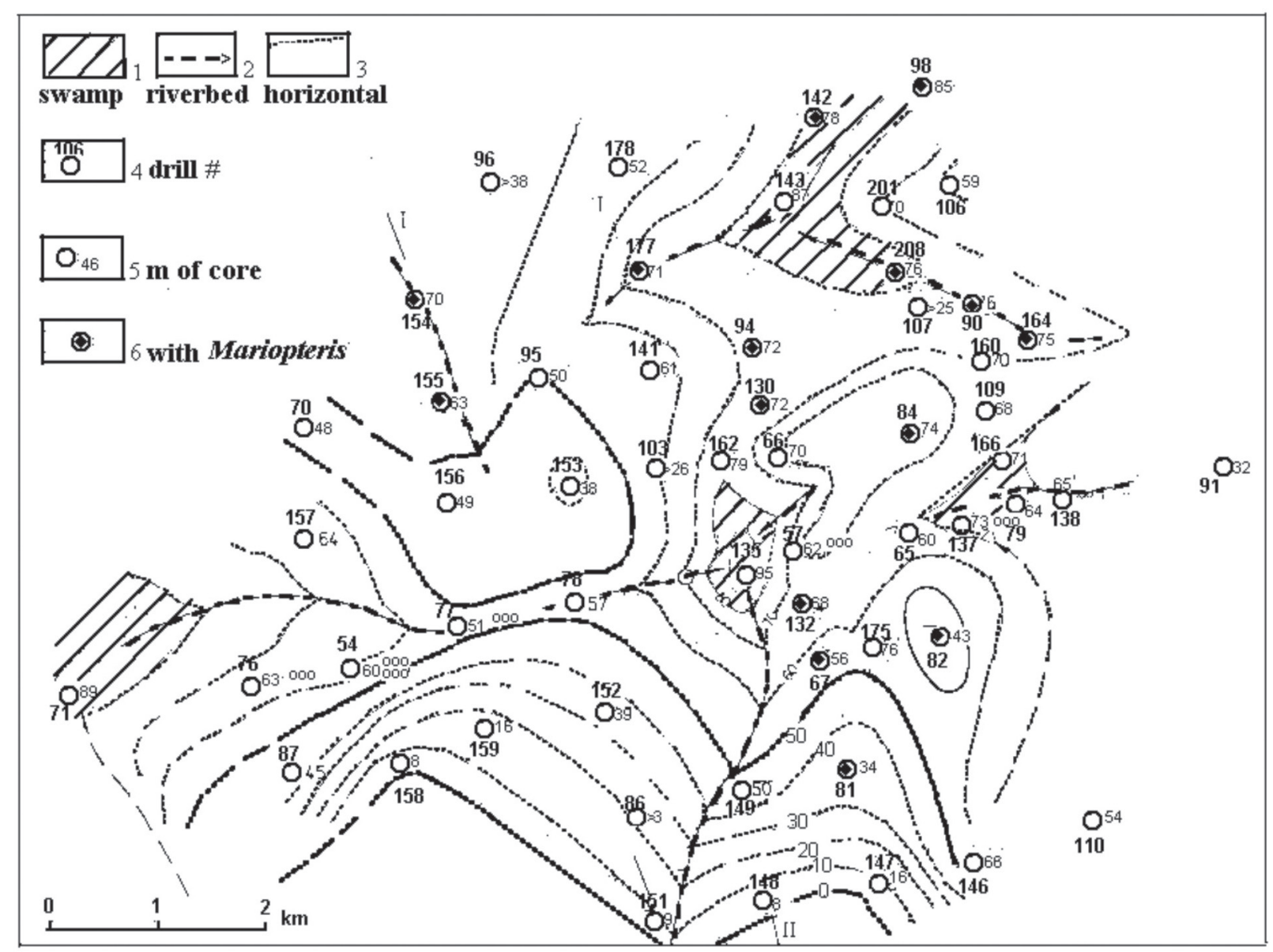

Fig. 5. Makedonka Formation below the m5 coal seam showing occurrence of Mariopteris

C - early Stephanian. Two specimens are from the Namurian A (the top of Rakovski Formation). The species distribution in the sequence is shown in Fig 1.

From their association with sedimentary environments it has been established (Tenchov, 2012) that the mariopterids existed on flood plains and levees as creeping plants. They are rarely present in large marsh-lake settings (especially in the Makedonka F.) and are absent from the fluvial sandstones of the Vranino F. and Velkovo F. The sequence and the species composition in the lower part of the Makedonka F. (below the m5 coal seam) permit a discussion on the plant composition in the area to the south of Seltse fault (Fig. 5). The environment here consists of an alluvial plain covered with sand, small swamps, levees and riverbeds dammed by landslides. Mariopteris remains occur mainly in and near the swamp deposits.

The vegetation associated with mariopterids (Table 1) is of Sphenophyllum, Paripteris with single vein meshes or Linopteris with imperfect reticulation, Lonchopteris, Lyginopteris, Eusphenopteris, and rare ferns. It is a similar situation to that in Svoge Coalfield, which is influenced by the lower temperature (Tenchov, 2011).

The sandy substrates were deeply drained and so the water supply of the plants depended mainly on regular rainfall. The atmosphere humidity was low as indicated by the vein reticulation in paripterids, and the transition of Neuropteris obliqua to Reticulopteris, evidence of which first appears below coal seam m5. The drying went in parallel with cooling, which provoked considerable changes in species composition, which is particularly well expressed from the beginning of Duckmantian times. Among the mariopterids $M$. beneckeii did not survive; $M$. muricata and $M$. nervosa became rare; and $M$. carnosa appeared in the DC. About mid-Bolsovian times, the drying caused diminished input of sandstones into the depression, and in the surrounding upland areas deep weathering led to increased quartz composition of the sediments and maybe a diminishing of the vegetated areas. Some tectonic event or influence in the depression with water destroyed the water barrier to the north, and active erosion in the depression removed up to 133 metres sediment (Tenchov, 1993, Figs 7, 8). After some volcanic activity the dam is repaired, and volcanic ash and water created conditions for swamp vegetation. The resulting peat (coal seam m5) may be covered the whole depression. The supply of terrigenous deposits is low, mainly of clay particles. Swamp conditions were obviously not favourable for mariopterids and their remains become rare. Nevertheless, M. carnosa that reflected drier air entered the basin at this time. 
Table 1

Carboniferous vegetation associated with mariopterids in the Svoge and Dobrudzha coalfields

\begin{tabular}{|c|c|c|c|c|}
\hline & \multicolumn{2}{|c|}{ Svoge Coalfield } & \multicolumn{2}{|c|}{ Dobrudzha Coalfield } \\
\hline & Mariopteris & Associated & Mariopteris & Associated \\
\hline Cantabrian-Asturian & & & $\begin{array}{l}\text { M. robusta, } \\
\text { M. sarana }\end{array}$ & $\begin{array}{c}\text { Sphenophyllum, Alethopteris, } \\
\text { Callipteridium }\end{array}$ \\
\hline Bolsovian & & & M. sarana & Sphenophyllum, Alethopteris \\
\hline Duckmantian & M. nervosa & Sphenophyllum & $\begin{array}{l}\text { M. muricata, } \\
\text { M. nervosa }\end{array}$ & $\begin{array}{l}\text { Sphenophyllum, Alethopteris, } \\
\text { Lonchopteris }\end{array}$ \\
\hline Langsettian & $\begin{array}{l}\text { M. acuta, } \\
\text { M. muricata }\end{array}$ & $\begin{array}{l}\text { Sphenophyllum, } \\
\text { Neuralethopteris }\end{array}$ & $\begin{array}{l}\text { M. muricata, } \\
\text { M. nervosa }\end{array}$ & $\begin{array}{l}\text { Sphenophyllum, Alethopteris, } \\
\text { Lonchopteris, Neuralethopteris }\end{array}$ \\
\hline Namurian C & $\begin{array}{l}\text { M. acuta, } \\
\text { M. muricata }\end{array}$ & $\begin{array}{l}\text { Sphenophyllum, } \\
\text { Neuralethopteris }\end{array}$ & $\begin{array}{l}\text { M. acuta, } \\
\text { M. muricata, } \\
\text { M. beneckeii }\end{array}$ & $\begin{array}{l}\text { Sphenophyllum, Alethopteris, } \\
\text { Lonchopteris, Neuralethopteris }\end{array}$ \\
\hline Namurian A & & & M. acuta & $\begin{array}{c}\text { Sphenophyllum, Alethopteris, } \\
\text { Neuralethopteris }\end{array}$ \\
\hline
\end{tabular}

The filling of the depression with quartz sand of the Krupen F was interrupted three or four times by coal deposition. In the deposits overlying the coal seams, mariopterids briefly return to the depression. However, their decline continued and thereafter only Dicksonites entered the depression.
These climatic changes are reflected in changes in the mariopterids of the DC, which can be summarised in several phases (Fig. 6).

Phase 1 occurs between SL 1 to 50. Favourable conditions (high $\mathrm{CO}_{2}$ content, temperature, humidity and low input of sand) encouraged the acceleration in frond
Mariopteris acuta

Mariopteris muricata

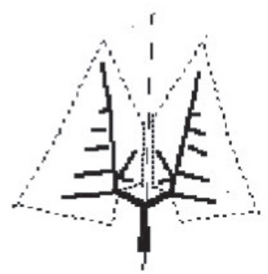

after Dancé-Corsin bipartite at the top

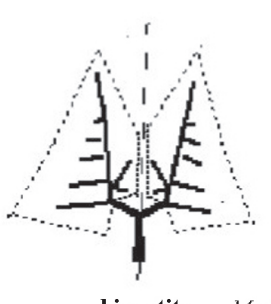

bipartite Mariopteris Zeiller

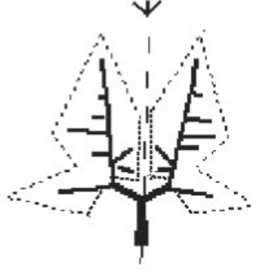

quadripartite

(Karinopteris Boersma)

Appearence

Acceleration

Namurian C

Namurian A

(Mariopteris Zeiller, Boersma emend)
Mariopteris robusta

Mariopteris soubeirianii

Mariopteris carnosa

Mariopteris nervosa
Retardation Disappearance

Westphalian A-B Cantabrian

Fig. 6. Phases in architecture building of mariopterids 
building, resulting in $M$. muricata being derived from $M$. acuta. The genetic connection between them was indicated to some extend by Huth (1912) and Danzé-Corsin (1953, p. 85). The bipartite top part of M. muricata indicates the same.

Phase 2 starts between SL 50 to SL 450, when sandstones prevail. They indicate active erosion south of the basin's delimiting fault and fluvial sedimentation in the DC depression. The small size of swamps is indicated by the absence of correlatable coal seams. From SL 360 to SL 600 there is evidence of declining humidity, which promoted vein reticulation in the pteridosperms (Tenchov, 2012). The mariopterids show evidence of gradual change. The tendency towards drier conditions caused diminishing denticulation and undulation of the pinnules and dense veining. These were retardation in the frond architecture of $M$. muricata; the pinnules with reduced size and border undulations that indicate $M$. nervosa occur earlier then in France. In addition, the disappearance of $M$. acuta occurs later than in France (Laveine, 1986).

Phase 3 embraces the interval from SL 670 to SL 870. Large swamp conditions diminish and so the mariopterids that grew there become rare.

Phase 4 is represented between SL 870 and SL 1120. The erosion in the upland was replaced by strong weathering that led to quartz sand and rare vegetation. The rarer rains introduced quartz sands of the Velkovo Formation and overlaying strata. Those sands contain practically no determinable plants, only dry barks. For a short time interval, mariopterids occurred in the DC in the beds immediately overlying the coal seams of the Krupen F., but after that only $M$. nervosa and $M$. carnosa are found rarely.

Phase 5 is marked from SL 1120 to SL 1600. The strong drying is indicated by numerous red beds, quartz veins in the coals, and drying cracks in the beds immediate overlying the coal seams (Fig. 7). It is marked by the appearance of Dicksonites plukenetii about the end of Asturian times (SL 1104) and the disappearance of the mariopterids (SL 1246).

Phase 6 (above SL 1600) yields no information on the plant cover in NE Bulgaria. Uplift and erosion of the DC depression occurred shortly before early Permian times.

The sequence of mariopterids in the French coal fields is broadly similar to that seen in the Dobrudzha Coalfield, indicating that they were the result of similar climatic changes.

\section{CONCLUSION}

The study of Mariopteris from Dobrudzha Coalfield has yielded evidence of an attached seed, providing the evidence that has been long sought for the pteridosperms affinities of this genus. The established creeping habit

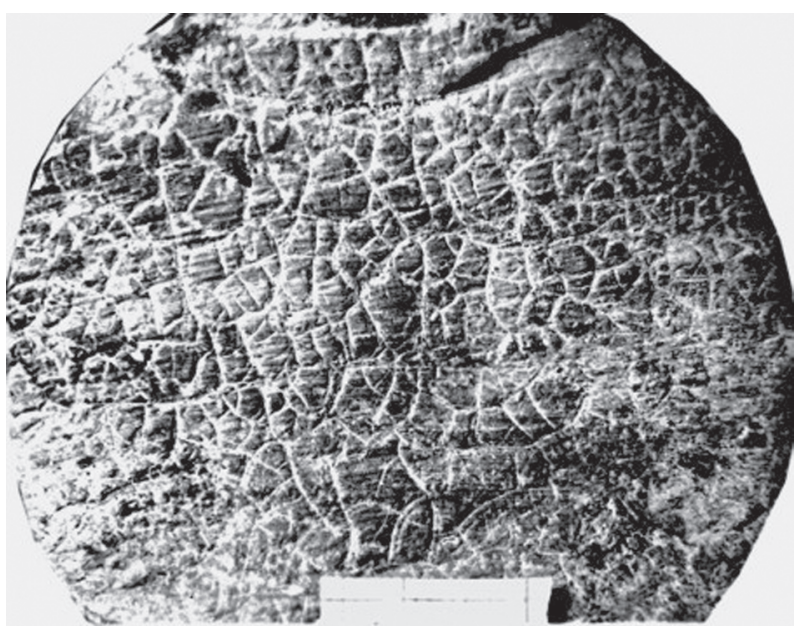

Fig. 7. Drying cracks in beds immediately overlying coal seam p3, Dobrudzha Coalfield. Sample 15467, drill 199, 1488 m (SL 1234), Gurkovo Formation, Cantabrian. Scale in $\mathrm{mm}$

of these plants might provoke more critical notes than acceptance. The main part of the studied Carboniferous land plants is connected to the beds immediately overlying coal seams and reflects the coal-building flora. Nowadays, when large areas in open mines are available for fieldwork, it is possible to search more completely the intervals between coal seams, including the sediments of the flood plain. In the Svoge Coalfield there are also several large outcrops rich in Mariopteris in flood-plain conditions, all of them with Mariopteris acuta (localities 71, 94, and 107, in Tenchov, 1977).

\section{Storage of samples}

At present, 3600 samples are available for public access at the Museum of Palaeontology and Stratigraphy, University of Mining and Geology "St. Ivan Rilski". These include 43 exposed and 109 packed samples of Mariopteris and Dicksonites. The information for their places of display and packing is available electronically at the museum. Another 5000 samples are still not publicly accessible, and the search for a suitable place of deposition for them is ongoing.

\section{Acknowledgments}

Chritopher Cleal (Cardiff) is thanked for detailed discussions on these fossils and for the thorough review of the text. IGCP Project 575 ensured financial support to visit the Zagreb Meeting in 2011, where a short version of the present article was presented. 


\section{REFERENCES}

Boersma, M. 1969. A fertile leaf of "Mariopteris latifolia". Mededelingen Rijks Geologische Dienst, Niewe Serie 20, 65-77.

Boersma, M. 1972. The heterogenity of the form genus Mariopteris Zeiller. Atlas. $172 \mathrm{pp}$.

Corsin, P. 1932. Mariopteridees. Etudes des gites minereaux de la France, Bassin houiller de la Sarre et de la Lorraine. I. Flore fossile 3, 111-173.

Danzé-Corsin, P. 1953. Contribution a l'étude des Mariopteridees. Les Mariopteris du Nord de la France. Études Géologique, Atlas Topographique Soutèrrain, Service Géologique H. B. N. P. C. 1(1), 269 pp.

Gothan, W. 1913. Die oberschlesische Steinkohlenflora. I. Farne und faranliche Gewachse. Abhandlungen der Königlich Preussischen geologischen Landesanstalt, n. F., $278 \mathrm{pp}$.

Gothan, W. 1935. Die Steinkohlen Flora der westlichen paralischen Steinkohlenreviere Deutschlands. Lieferung $3 \mathrm{Ab}$ handlungen der Preussischen geologischen Landesanstalt, $1-82$.

Huth, W. 1912. Mariopteris. In: Potonie, H. (Ed.), Abbildungen und Beschreibungen fossiler Pflanzen-Reste. Königlich Preußische Geologische Landesanstalt und Bergakademie $8,140-160$.

Kidston, R. 1925. Fossil plants of the Garboniferous rocks of Great Britain. Memoir Geological Survey Great Britain, Palaeontology 2(6).
Laveine, J.-P. 1986. La flore du bassin houiller du Nord de la France. Biostratigraphie et methodologie. Annales Sociètè Géologique du Nord, T CVI, 87-93.

Љtur, D. 1885. Beiträge zur Kenntnis der Flora der Vorwelt 2 (1 Abt.) Die Carbon-Flora der Schatzlarer Schichten. Die Farne der Carbon-Flora der Schatzlarer Schichten Abhandlungen der Kaiserlich-königlichen Geologischen Reichanstalt 11(1), 418 pp.

Tenchov, Y.G. 1977. Flora und Biostratigraphie des Oberkarbons in Svoge-Becken (VR

Bulgarien). Schriftenreihe für geologische Wissenschaften. Berlin, Akademische Verlag, 164 pp.

Tenchov, Y. 1993. Sedimentation and erosion during the Late Carboniferous in the Dobrudza Coal Field (North-East Bulgaria). Geologica Balcanica 23(2), 3-18.

Tenchov,Y.G. 2011. Peculiarities in the composition of the Carboniferous megaflora in Svoge and Dobrudzha coalfields (Bulgaria). Bulletin of the Natural History Museum 4, 37-49.

Tenchov, Y.G. 2012. Structure, habitat and seed of Mariopteris Zeiller. Geologia Croatica 65(3), 361-366.

Zeiller, R. 1878. Vegetaux fossiles du terrain Houiller de la France. Atlas.

Zeiller, R. 1879. Vegetaux fossiles du terrain Houiller de la France. Explications de la Carte géologique de la France 4 (2), $185 \mathrm{pp}$.

Zeiller, R. 1886-1888. Vegetaux fossiles du bassin houiller de Valensiennes. Etude des gites minereaux de la France. $731 \mathrm{pp}$. 